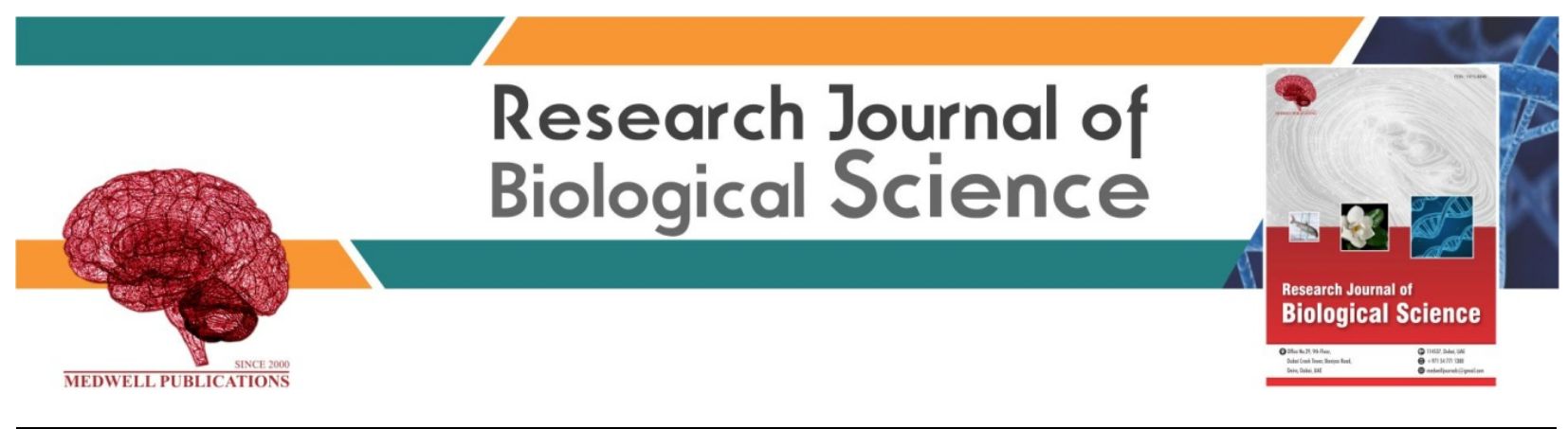

\title{
Biological Activity of Banana (Musa sapeintum and Musa cavandish) Fruit Peel
}

\author{
${ }^{1}$ A. Abd-Elsamad, ${ }^{1}$ Nadia M. Abdelmoein, ${ }^{2}$ Amal H. Mahmoud, ${ }^{2}$ Merit Rostom and ${ }^{3}$ Shaimaa M. Hassan \\ ${ }^{1}$ Department of Biochemistry, Faculty of Agriculture, Cairo University, Giza, Egypt \\ ${ }^{2}$ Food Technology Research Institute, Agricultural Research Center, Giza, Egypt \\ ${ }^{3}$ Academy of Scientific Research and Technology (ASRT), Cairo, Egypt
}

Key words: Musa sapientum and Musa cavandish, proximate analysis, antioxidant, antimicrobial, anti cancer, HPLC

Corresponding Author:

A. Abd-Elsamad

Department of Biochemistry, Faculty of Agriculture, Cairo University, Giza, Egypt

Page No.: 40-52

Volume: 15, Issue 2, 2020

ISSN: $1815-8846$

Research Journal of Biological Sciences

Copy Right: Medwell Publication
Abstract: The chemical composition of banana (Musa sapeintum and Musa cavandish) peel were studied. The proximate analysis was found to be 89.63 and 86.43 moisture and 12.48 and 7.65 crude protein and 3.86 and 14.05 total lipid and 18.5 and 12.26 ash, 14.61 and 16.36 crude fiber, 50.55 and 49.23 total available carbohydrate in peel of Musa sapientum and Musa cavandish., respectively. The ash contained (mg/100 g) 96.58 and $60.68 \mathrm{mg}$ and 137.69 and $81.71 \mathrm{Na}$ and 0.75 and $1.48 \mathrm{Zn}$ and 3.80 and $2.11 \mathrm{Fe}$ and 102.25 and $43.12 \mathrm{Ca}$ and 3804.73 and $2882.12 \mathrm{~K}$ in peel, respectively, antimicrobial activity of Musa sapientum and Musa cavandish were found to be the methanolic extract more effective than all other extracts on bacteria and fungi. Oppositethat in anti-cancer activity of Musa sapientum and Musa cavandish were found to be the methanolic extract not effective compare with all other extracts on Hepatic cell cancer (HEP G2) and colonic cell cancer (HCT). The phenolic compound contents (mg/100 g) were determined of Musa sapeintum and Musa cavandish peel, methanolic extract The results show the presence of pyrogallol (31.98 and 63.98) catechein (21.55 and 16.33), gallic (58 and 3.22), vanillic (2.94 and 4.46) ellagic (5.57 and 1.48), protocatchoic (1.22 and 3.09) and catechein (21.55 and 16.32), e-vanilic (19.6 and 7.23) salycilic (25.53 and 1.13), respectively.

\section{INTRODUCTION}

Different species of Musa genus (Family: Musaceae), commonly known as banana are native to the Asian, Indo-Malaysian and Australian tropics and are now widely found throughout the tropical and subtropical areas $^{[1,2]}$. Banana grown in all governorates of Egypt and available throughout the year, banana currently occupies a total area of 72953 Fadden. The productive area of which is 60090 Fadden produces about 1158224 tons with an average production per Fadden 19.28 tons $^{[3]}$. Significant quantities of banana peels, equivalent to $40 \%$ of the total weight of fresh banana are generated as a waste product in industries producing banana based products $^{[4]}$. Potential applications for banana peel depend on its chemical composition. Banana peel is rich in dietary fiber, proteins, essential amino acids, polyunsaturated fatty acids and potassium ${ }^{[5]}$.

Banana peels are major agricultural wastes which have been used as medicine, animal feeds, blacking of 
leathers, soap making, fillers in rubber and so on ${ }^{[6]}$. Fruit wastes are highly perishable and seasonal and are a problem to the processing industries and pollution monitoring agencies. This problem can be recovered by utilizing its high value compounds including the dietary fiber fraction that has a great potential in the preparation of functional foods ${ }^{[7]}$. Banana peel, an underutilized source of phenolic compounds is considered as a good source of antioxidants for foods and functional foods against cancer and heart disease ${ }^{[8]}$. The peel of the fruit contains various antioxidant compounds such as gallocatechin $^{[8]}$ and dopamine ${ }^{[7]}$.

Antifungal and antibiotic principles are found in the peel and pulp of fully ripe bananas ${ }^{[9]}$. The antibiotic acts against mycobacteria ${ }^{[10]}$. Norepinephrine, dopamine and serotonin are also, present in the ripe peel and pulp ${ }^{[11]}$. The first two elevate blood pressure, serotonin inhibits gastric secretion and stimulates the smooth muscle of the intestines $^{[12]}$.

Banana fruit and peel are effective in the treatment of various conditions, from the treatment of simple bruises to reducing the pain in flares of arthritis and even possibly having anti cancer properties ${ }^{[13]}$. The natural bioactive compounds in fruits such as carotenoids, quercetin derivatives, phenolic acids and saponins are originally found in the peels with higher concentration towards the flesh ${ }^{[14]}$.

Mordi et al. ${ }^{[15]}$ the banana peel is simply discarded as rubbish, although, in certain areas, it is used as animal feed. Although, banana peel is biodegradable, its disposal causes unsightly pollution. With this environmental concern in mindand some beneficial uses of banana, it was decided to investigate the usefulness of the peel with the aim of extracting and identifying any useful chemicals that may be available in it.

\section{MATERIALS AND METHODS}

Plant material: Fresh banana of two varieties were purchased one from Carrefour market (Musa cavendish) and another one from Al Obour market (Musa sapantium) in one lot and processed. Banana peel were cleaned using distilled water and dried in an oven at $40 \pm 1^{\circ} \mathrm{C}$ for $72 \mathrm{~h}$. The peels were powdered using lab grinder. Then stored in an air-tight jars maintained at $-4^{\circ} \mathrm{C}$ until extraction.

Preparation of different plant extracts: The powdered air dried of banana peel (600 g) were subjected separately to exhaustive continuous successive extraction using shaker. Different extracts were obtained using the following solvents according to their polarities (in ascending order) hexane, ethyl acetate, methanol and deionized water. The different solvents were completely removed under reduced pressure using rotary evaporator at a temperature not exceeding $50^{\circ} \mathrm{C}$. The residue in each case was dried in under vacuumed. The obtained extracts were stored in refrigerator $\left(4^{\circ} \mathrm{C}\right)$ till chemical analysis and biological assay.

Chemical composition of the dried peel of Musa sapeintum and Musa cavendish: Chemical composition such as moisture, ash content, crude protein, crude fiber, total lipid, total carbohydrate (by difference) and mineral content of banana peel (Musa sapeintum and Musa cavandish) were determined according to the methods of AOAC. ${ }^{[16]}$.

Separation and identification of chemical components of Musa sapeintum and Musa cavendish and extracts by HPLC: HPLC Agilent 1200 series equipped with quaternary pump, autosampler, column compartments ET at $35^{\circ} \mathrm{C}$, malti wavelength detector set at 330 and $280 \mathrm{~nm}$ for detection of flavonoid compounds and phenolic compounds, degasser, column used for fractionation Zorbax OD. $4.6 \times 250 \mathrm{~mm}$ and the flow rate of mobile

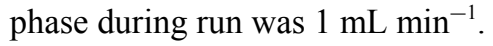

Chromatographic analysis of phenolic compounds: The phenolic compounds of black mulberry methanolic extract were fractionated and identified by HPLC according to the method described by Goupy et al. ${ }^{[17]}$.

Chromatographic analysis of flavonoid compounds: Flavonoid compounds of black mulberry methanolic extract according to the method described by Mattila et $a l .{ }^{[18]}$.

\section{Determination of fatty acids}

Separation of fatty acids: Lipid was saponified with ethanolic $\mathrm{KOH}(20 \% \mathrm{w} / \mathrm{v})$ for $24 \mathrm{~h}$ at room temperature. The aqueous layer was acidified by HCL (20\% w/v) and the liberated fatty acids were extracted with diethyl ether ${ }^{[19]}$.

Preparation of fatty acid methyl ester: Fatty acids of standards and samples were converted to methyl esters using ethereal solution of diazomethane. Fatty acids were dissolved in $0.5 \mathrm{~mL}$ anhydrous diethyl ether and methylated by dropwise addition of diazomethane solution until the yellow color persisted ${ }^{[20]}$. The mixture was then left at room temperature for $15 \mathrm{~min}$ and the solvent was evaporated on a water bath maintained at $60^{\circ} \mathrm{C}$. Finally, the fatty acid methyl esters were dissolved in pure chloroform and aliquots of this solution were subjected to GLC analysis.

Fractionation of Musa sapeintum and Musa cavendish fatty acid by GLC method: The methyl esters of Musa sapeintum and Musa cavendish fatty acid and standard compounds were analyzed by using HP 6890 
GC capillary column gas liquid chromatography with a dual flame ionization were carried out on $(30 \mathrm{~m} \times 0.32$ $\mathrm{mm} \times 0.25 \mu \mathrm{m}) \mathrm{DB}-225$ capillary column, stationary phase ( $50 \%$ cyan propyl phenyl $+50 \%$ dimethyl polysiloxane). Column temperature; initial temperature was $150^{\circ} \mathrm{C}$, the temperature was programmed by increasing the temperature from $150-170^{\circ} \mathrm{C}$ at the rate of $10^{\circ} \mathrm{C} \mathrm{min}^{-1}$, then increased from $170-192^{\circ} \mathrm{C}$ at the rate of $5^{\circ} \mathrm{C} \mathrm{min}^{-1}$, holding for five min and then increased from $192-220^{\circ} \mathrm{C}$ during $10 \mathrm{~min}$, holding three $\mathrm{min}$. The injector and detector temperature were 230 and $250^{\circ} \mathrm{C}$, respectively. Carrier gas, hydrogen flow rate $40 \mathrm{~mL} \mathrm{~min}^{-1}$ and air flow rate was $450 \mathrm{~mL} \mathrm{~min}^{-1}$. Peak identification was established by comparing the retention times obtained with standard methyl esters. The area under the chromatographic peak were measured with electronic integrator $^{[16]}$.

\section{In vitro antioxidant study \\ Determination of radical scavenging activity in banana peel: The free radical scavenging effect of each extract was assessed by the discoloration of a methanolic solution of 2, 2-diphenyl-1-picryl hydrazyl (DPPH) radical (violet color) according to the method of Brand-williams et al. ${ }^{[21]}$.}

Determination of total phenolic compounds in banana peel: The concentration of total phenolic compounds in the methanolic extract $(1: 10)$ was determined by using folin-ciocalteu's reagent according to Singleton and Rossi $^{[22]}$. Calibration curve was prepared using gallic acid as standard for TPC which was measured as mg Gallic Acid Equivalents (GAE) per milliliter of the sample $(\mu \mathrm{g} / \mathrm{mL})$.

Determination of total flavonoid of banana peel: The colorimetrically method as described by Hoslattmann and Hoslattmann $^{[23]}$ was used to determine total flavonoids contents.Calibration curve was prepared using quercetin as standard for total falvonoid which was measured as $\mathrm{mg}$ Quercetin Equivalents (QE) per milliliter of the sample $(\mu \mathrm{g} / \mathrm{mL})$.

Antimicrobial activity The antimicrobial activity of black mulberry extracts was determined by the disk diffusion methods ${ }^{[24]}$. The Minimum Inhibitory Concentrations (MIC) were determined according to Cheesbrough $^{[25]}$.

Bacterial strain: Four bacterial strains of significant importance were used to test the antibacterial properties of the essential oils. Two of them were Gram positive (Bacillus cereus ATCC6538 and Staphylococcus aureus ATCC25923) and the others were Gram negative (E. coli ATCC25922 and Salmonella typhimurium ATCC9027). The cultures of strains used in this study were obtained from Microbiological Resources Centre (MIRCEN), Faculty of Agriculture, Ain Shams University and Cairo, Egypt. Bacterial strains were inoculated into Mueller Hinton Broth (Difco) and incubated at $37^{\circ} \mathrm{C}$ for $24 \mathrm{~h}$. The cultures were subjected to three successive 24 h. transfers before use. All cultures were adjusted to 106 CFU per $\mathrm{mL}$ prior to use 2 .

Disk diffusion assay: About $20 \mathrm{~mL}$ of Muller Hinton agar was placed into $10 \mathrm{~mL}$ petri dishes and $0.1 \mathrm{~mL}$ of the active cultures was spread over the plate using a sterile glass spreader in order to get a uniform microbial growth for all plates ${ }^{[26]}$.

\section{Anticancer activity}

Measurement of potential cytotoxicity by SRB assay: Potential cytotoxicity of the compounds were tested using the method of Skehan et al. ${ }^{[26]}$. Cells were plated in 96-multiwell plate (104 cells/well) for $24 \mathrm{~h}$. Before treatment with the components to allow attachment of cell to the well of the plate. Concentration of the compound under test $\left(12.5,25,50,100 \mathrm{~g} \mathrm{~mL}^{-1}\right)$ was added to the cell monolayer triplicate wells were prepared for each individual dose. Monolayer cells were incubated with the compounds for $48 \mathrm{~h}$ at $37^{\circ} \mathrm{C}$ and inatomosphere of $5 \%$ $\mathrm{CO}_{2}$. After $48 \mathrm{~h}$, Cells were fixed, washed and stained with Sulfo rhodamine-B stain. Excess stain was washed with acetic acid and attached stain wise recovered with Tris EDTA buffer. Color intensity was measured in an ELISA reader. The relation between surviving fraction and drug conc is plotted to get the survival curve of each tumor cell line after the specified compound.

Statistical analysis: Data were subjected to the convenient statistical analysis methods. Where mean and standard error was calculated. Data were analyzed using two way-classifications ANOVA as described by Snedecor and Cochran followed by Duncans multiple comparison tests to find the statistical significant difference between the ten treated groups. Mean separation was done according to the Least Significant Differences (L.S.D ${ }_{5 \%}$ ) Duncans multiple range tests according to Waller and Duncan ${ }^{[27]}$.

\section{RESULTS AND DISCUSSION}

Chemical composition of banana peel of Musa sapientum and Musa cavendish

Proximate analysis: Data in Table 1 show the proximate analysis of banana peel Musa sapientum and Musa cavendish. The moisture content was found to be $89.62^{\mathrm{a}} \pm 0.4$ and $86.43^{\mathrm{b}} \pm 0.7 \%$ in Musa sapientum and Musa cavendish peel, respectively. These results are nearly the same to those of Waller and Duncan ${ }^{[27]}$ who found that $90.7 \%$ in Musa cavendishii species. 
Res. J. Biol. Sci., 15 (2): 40-52, 2020

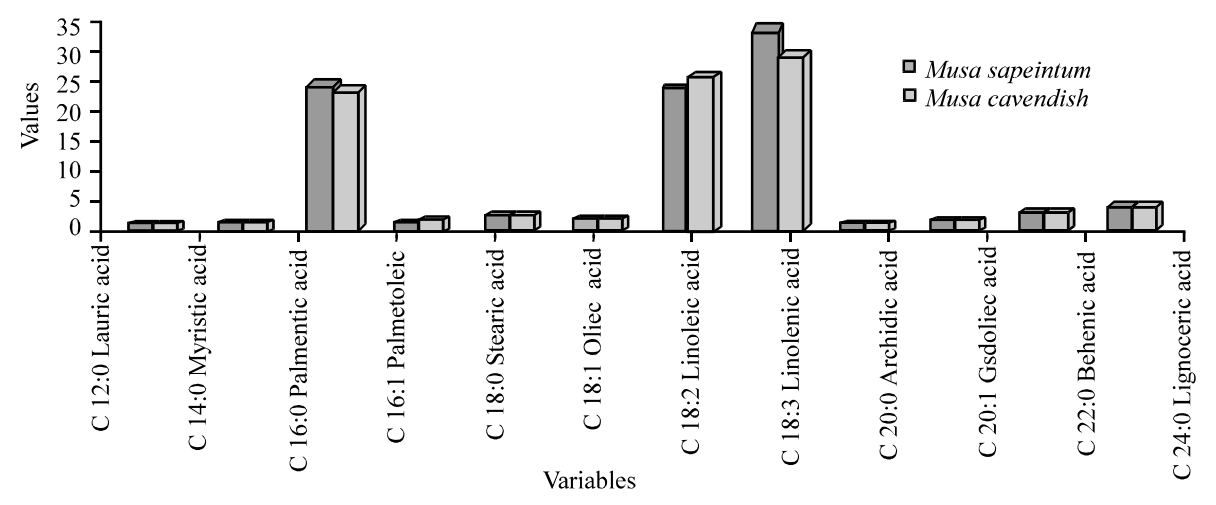

Fig. 1: Fatty acid content of banana peel

Table 1: Proximate analysis of Musa sapeintum and Musa cavendish (\% dry wt.)

\begin{tabular}{lcc}
\hline Chemical composition (\%) & Musa sapientum & Musa cavendish \\
\hline Moisture & $89.62 \pm 0.4^{\mathrm{a}}$ & $86.43 \pm 0.7^{\mathrm{b}}$ \\
Protein & $12.48 \pm 0.68^{\mathrm{a}}$ & $7.65 \pm 0.28^{\mathrm{b}}$ \\
Total lipid & $3.86 \pm 0.31^{\mathrm{a}}$ & $14.05 \pm 0.58^{\mathrm{b}}$ \\
Ash & $18.5 \pm 0.28^{\mathrm{a}}$ & $12.26 \pm 0.49^{\mathrm{b}}$ \\
Crude fiber & $14.61 \pm 0.62^{\mathrm{a}}$ & $16.36 \pm 0.40^{\mathrm{b}}$ \\
Total available carbohydrate & $49.83 \pm 0.35^{\mathrm{a}}$ & $48.76 \pm 0.25^{\mathrm{b}}$ \\
\hline
\end{tabular}

${ }^{\mathrm{a}, \mathrm{b}}$ Siguificut values

The protein content was found to be $12.48 \pm 0.68^{\mathrm{a}}$ and $7.65 \pm 0.28^{\mathrm{b}}$ in Musa sapientum and Musa cavendish peel, respectively. These results are slightly lower than those of Schmid et al. ${ }^{[28]}$ who found $15.8 \%$. While our results are nearly the same to that found by Yan et al ${ }^{[31]}$ who found it from 6.59-7.37 in different ripening stages on Musa cavendish pee ${ }^{[30,31]}$. The total lipid content was found to be $3.86 \pm 0.31^{\mathrm{a}}$ and $14.05 \pm 0.58^{\mathrm{b}}$, ash $18.5 \pm 0.28^{\mathrm{a}}$ and $12.26 \pm 0.49^{\mathrm{b}}$, total available carbohydrate by difference was $49.83 \pm 0.35^{\mathrm{a}}$ and $48.76 \pm 0.25^{\mathrm{b}}$ in Musa sapientum and Musa cavendish peel, respectively. According to Anhwange ${ }^{[32]}$, the ash content in banana peel was $8.5 \%$ which was lower than what hasbeen found in this study. The banana species Musa sapientum which were grown in Africa was studied by Anhwange ${ }^{[32]}$. Zafar et al..$^{[33]}$ tested the chemical composition of peels from three varieties of Musa paradaisica (varieties were Pachabale, Yelakkibale and Nendranbale) grown in Indiaand found that the ash content ranged from 8.9-12.96\%. However, samples in this study were Egyptian-grown Musa sapeintum, Ecuador-grown Musa cavendish. The variation in banana species and growing area could lead to the difference of chemical composition. The percentage of crude fiber of banana peel in this study was approximately $14.61 \pm 0.62^{\mathrm{a}}$ and $16.36 \pm 0.40^{\mathrm{b}} \%$ in Musa sapientum and Musa cavendish peel, respectively. These results are nearly the same to those of ${ }^{[28]}$ who found that $14 \%$ in Musa cavendishii species. However, Anhwange ${ }^{[32]}$ reported crude fiber contents of $31.7 \%$ in Musa sapientum. Such differences could be due to the differences in farming conditions and species; the bananas
Table 2: Fatty acid contents in Musa sapeintum and Musa cavendish \begin{tabular}{lcc}
\hline Variables & Musa sapeintum & Musa cavendish \\
\hline Cling
\end{tabular} \begin{tabular}{lcc}
\hline C12:0 Lauric acid & 0.411 & 0.37
\end{tabular} $\begin{array}{lll}\text { C14:0 Mristic acid } & 0.844 & 0.77\end{array}$ $\begin{array}{lr}\text { C16:0 Palmetic acid } & 24.49\end{array}$ C16:1 Palmetoleic acid $\quad 0.7 \quad 1.20$ $\begin{array}{lll}\text { C18:0 Stearic acid } & 2.5 & 2.50\end{array}$ C18:1 Oliec acid $\quad 1.4 \quad 1.20$ $\begin{array}{ll}\text { C18:2 Linoleic acid } & 23.7\end{array}$ C18:3 Linolenic acid $\quad 34.16 \quad 29.70$ $\begin{array}{lll}\text { C20:0 Arachidic acid } & 0.66 & 0.80\end{array}$ C20:1 Gadoliec acid $\quad 1.05 \quad 1.04$ $\begin{array}{lll}\mathrm{C} 22: 0 & \text { Behenic acid } & 2.6\end{array}$ $\begin{array}{llr}\text { C24:0 Lignoceric acid } & 3.4 & 3.90\end{array}$ $\begin{array}{lll}\text { Total saturated FA } & 31.5 & 34.74\end{array}$ \begin{tabular}{lll} 
Total unsaturated FA & 61.01 & 59.24 \\
\hline
\end{tabular}

studied by Anhwange ${ }^{[32]}$ were Musa sapientum from Zafar et al. (2011) found that the crude fiber content in banana peel fluctuated through the different maturation stages.

The yield of Musa sapeintum and Musa cavendish in different fractions: It is clear that the yield percentage of Musa sapeintum and Musa cavendish 5.52 and 3.39\%, 1.06 and $1.084 \%, 14.68$ and $12.71 \%$ and 17.3 and $11.99 \%$ in hexane fraction, ethyl acetate fraction, methanol fraction and aqueous extract fraction, respectively. These results are in agreement with Arawande and Komolafe ${ }^{[6]}$ who found that the yield percent of methanol extracts was next to acetic acid. The percent yield of extract in banana peel was higher than that of plantain peel in all the solvents used. According to the rule of thumb, natural antioxidants are polar (phenolic) compounds and they are best extracted using polar solvents ${ }^{[34]}$. Ethylacetate, acetone and chloroform yielded about 20-25\% (Fig. 1).

Fatty acid contents of Musa sapeintum and musa cavendish: Fatty acid contents of Musa sapeintum and Musa cavandish were shown in Table 2. The results show linolenic represent the major content (34.16 and 29.7\%) followed by linoleic (23.7 and 26.1\%) and palmitic (24.49 and $23.5 \%$ ) in Musa sapeintum and Musa cavandish peel, respectively. These results indicate that the peel have 
Res. J. Biol. Sci., 15 (2): 40-52, 2020

Table 3: Mineral contents in Musa sapeintum and Musa cavendish

\begin{tabular}{lllllll}
\hline Mineral as $(\mathrm{mg} / 100 \mathrm{~g})$ & $\mathrm{Fe}$ & $\mathrm{Zn}$ & $\mathrm{Ca}$ & $\mathrm{Na}$ & $\mathrm{Mg}$ & $\mathrm{K}$ \\
\hline Musa sapeintum & $3.87 \pm 0.05^{\mathrm{a}}$ & $0.8 \pm 0.05^{\mathrm{b}}$ & $106.9 \pm 4.04^{\mathrm{a}}$ & $134.69 \pm 3.6^{\mathrm{a}}$ & $95.25 \pm 4.1^{\mathrm{a}}$ & $3804.73 \pm 40.09^{\mathrm{a}}$ \\
Musa cavendish & $2.11 \pm 0.2^{\mathrm{b}}$ & $1.63 \pm 0.2^{\mathrm{a}}$ & $45.12 \pm 2.5^{\mathrm{b}}$ & $81.71 \pm 4.6^{\mathrm{b}}$ & $66.68 \pm 4.9^{\mathrm{b}}$ & $2883.78 \pm 7.6^{\mathrm{b}}$ \\
\hline
\end{tabular}

Table 4: Radical scavenging activity in Musa sapeintum

\begin{tabular}{|c|c|c|c|c|c|}
\hline Concentration (\%) & Hexane extract & Ethyl acetate extract & Methanol extract & Water extract & Ascorbic acid (st) \\
\hline 20 & $18.99 \pm 3.5^{\mathrm{e}}$ & $13.63 \pm 2.3^{\mathrm{d}}$ & $21.92 \pm 0.5^{\mathrm{e}}$ & $12.06 \pm 1.3^{\mathrm{e}}$ & $92.05 \pm 2.2^{\mathrm{ab}}$ \\
\hline 40 & $32.8 \pm 2.9^{d}$ & $21.6 \pm 3.2^{\mathrm{c}}$ & $45.31 \pm 3^{\mathrm{d}}$ & $18.22 \pm 1.8^{\mathrm{d}}$ & $92.21 \pm 2.7^{\mathrm{b}}$ \\
\hline 60 & $48.3 \pm 5.6^{\mathrm{c}}$ & $37.89 \pm 1^{\mathrm{b}}$ & $62.55^{\mathrm{c}} \pm 1.4$ & $23.58 \pm 2^{\mathrm{c}}$ & $95.36 \pm 2.3^{\mathrm{ab}}$ \\
\hline 80 & $71.1 \pm 4.3^{\mathrm{b}}$ & $40.71 \pm 3.6^{\mathrm{b}}$ & $74.8^{\mathrm{b}} \pm 1.2$ & $34.84 \pm 2.3^{b}$ & $97.34 \pm 2.1^{\mathrm{ab}}$ \\
\hline 100 & $82.02 \pm 2^{\mathrm{a}}$ & $47.91 \pm 5.3^{\mathrm{a}}$ & $87.36^{\mathrm{a}} \pm 0$ & $46.07 \pm 1^{\mathrm{a}}$ & $98.16 \pm 3.5^{\mathrm{a}}$ \\
\hline LSD 0.05 & 5.5 & 6.22 & 2.86 & 3.12 & 4.82 \\
\hline
\end{tabular}

Table 5: Radical scavenging activity in Musa cavandish

\begin{tabular}{lccccc}
\hline Concentration (\%) & Hexane extract & Ethyl acetate extract & Methanol extract & water extract & Ascorbic acid as (st) \\
\hline 20 & $10.22 \pm 1.7^{\mathrm{e}}$ & $14.08 \pm 2.1^{\mathrm{e}}$ & $19.42 \pm 5.4^{\mathrm{e}}$ & $10.63 \pm 2.4^{\mathrm{c}}$ & $92.05 \pm 2.2^{\mathrm{ab}}$ \\
40 & $24.7 \pm 3.5^{\mathrm{d}}$ & $22.1 \pm 3.22^{\mathrm{d}}$ & $35.21 \pm 2.2^{\mathrm{d}}$ & $22.31 \pm 2.7^{\mathrm{b}}$ & $92.21 \pm 2.7^{\mathrm{b}}$ \\
60 & $33.6 \pm 3.5^{\mathrm{c}}$ & $30.94 \pm 2.9^{\mathrm{c}}$ & $55.03 \pm 7.1^{\mathrm{bc}}$ & $39.17 \pm 4^{\mathrm{a}}$ & $95.36 \pm 2.3^{\mathrm{ab}}$ \\
80 & $49.5 \pm 4.1^{\mathrm{b}}$ & $41.71 \pm 3.5^{\mathrm{b}}$ & $69.52 \pm 3.2^{\mathrm{b}}$ & $41.92 \pm 3.5^{\mathrm{a}}$ & $97.34 \pm 2.1^{\mathrm{ab}}$ \\
100 & $68.3 \pm 5^{\mathrm{a}}$ & $50.52 \pm 6.7^{\mathrm{a}}$ & $85.97 \pm 4.6^{\mathrm{a}}$ & $44.52 \pm 4.9^{\mathrm{a}}$ & $98.16 \pm 3.5^{\mathrm{a}}$ \\
LSD 0.05 & 6.58 & 5.7 & 6.2 & 6.4 & 4.82 \\
\hline
\end{tabular}

${ }^{\mathrm{a}-\mathrm{d}}$ Siguificut values

high concentration of essential fatty acids. The peel contains $31.5 \%$ saturated acids $(24.49 \%$ palmitic, $2.5 \%$ stearic, $0.66 \%$ arashidic) and $61.01 \%$ unsaturated acids (34.16\% linolenic acid, $23.7 \%$ linoleic and $1.4 \%$ oleic) in Musa sapeintum $34.74 \%$ saturated acids (23.5\% palmitic, $2.5 \%$ stearic, $0.8 \%$ arashidic) and $59.24 \%$ unsaturated acids (29.7\% linolenic acid, 26.1\% linoleic and 1.2\% oleic) in Musa cavandish. These results are agreement with $^{[35]}$ who found that the fatty acid content palmitoleic acids $(0.92,2.79$ and $4.6 \%$, respectivily), palmitic acid (29.18, 30.57 and $43.17 \%$, respectivily), linoleic acid $14.36,36.10$ and $21.82 \%$, respectivily), linolenic acid $(35.93,30.46$ and $39.68 \%$, respectivily) and stearic acid (3.76, 3.34 and $3.32 \%$, respectivily). In three varieties of banana and higher than ${ }^{[36]}$ who found that myristic acid $(0.5 \%)$, palmetoleic acid (1.2\%), palmeticacid $(11.6 \%)$, linoleic acid (9.6\%), linolenic acid (11.78\%), stearic acid $(1.45 \%)$ arachidic acid $(0.399 \%)$ and behenic acid $(1.43 \%)$.

Minerral content of Musa sapeintum and Musa cavendish: Table 3 show that the ash mineral content of Musa sapeintum and Musa cavendish (as mg/100 g). It is clear that potassium represents the high content of Musa sapeintum and Musa cavendish (3804.73 mg/100 g) and $(2882.12 \mathrm{mg} / 100 \mathrm{~g})$ respectively., followed by sodium $(137.69 \mathrm{mg} / 100 \mathrm{~g})$ and $(81.71 \mathrm{mg} / 100 \mathrm{~g})$ and calcium in Musa sapeintum $(102.26 \mathrm{mg} / 100 \mathrm{~g})$. The high ash (minerals) content in banana peel indicates its potential in food applications. Anhwange ${ }^{[31]}$ found that banana peels contained high potassium $\left(78.10 \mathrm{mg} \mathrm{g}^{-1}\right)$ and manganese $\left(76.20 \mathrm{mg} \mathrm{g}^{-1}\right)$. Emaga et al. ${ }^{[5]}$ concluded that the potassium was the most important mineral in banana peels.

Data in Table 4 and 5 and Fig. 2 and 3 illustrate the DPPH free radical scavenging effect of different successive extracts of Musa sapeintum and Musa

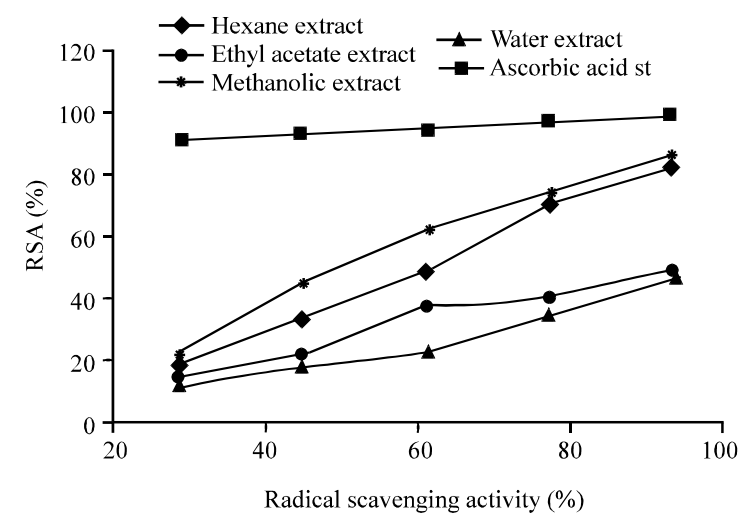

Fig. 2: Radical scavenging activity of different Musa sapeintum peel extracts

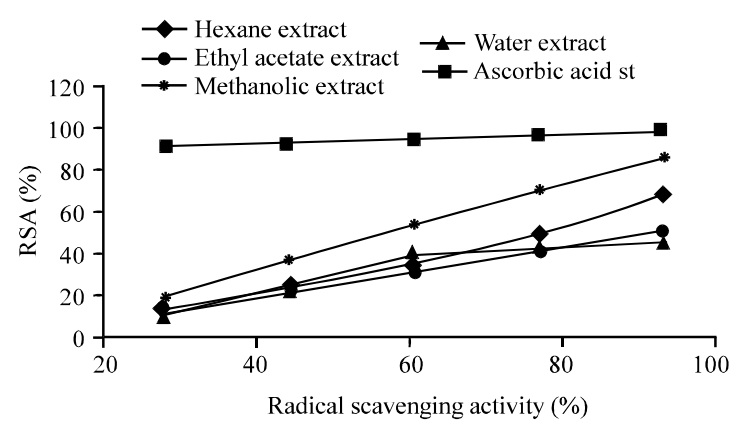

Fig. 3: Radical scavenging activity of different Musa cavendish peel extracts

cavendish all the tested extracts show appreciable free radical scavenging activities. The antioxidant activity of the extracts obtained in this study was determined using DPPH method because it is one of the most effective methods for evaluating radical-scavengers. Ascorbic acid 
Res. J. Biol. Sci., 15 (2): 40-52, 2020

Table 6: The total phenolic compounds and total flavonoid compounds of Musa sapeintum and Musa cavendish

\begin{tabular}{lcc}
\hline Variables & $\begin{array}{c}\text { Total phenol } \\
\mathrm{mg} \mathrm{g}^{-1} \text { gallic acid }\end{array}$ & $\begin{array}{c}\text { Total flavonoid } \\
\mathrm{mg} \mathrm{g}^{-1} \text { quercetine }\end{array}$ \\
\hline Powder Musa sapeintum & $15.40 \pm 5.7^{\mathrm{e}}$ & $14.33 \pm 1.6^{\mathrm{e}}$ \\
Powder Musa cavendish & $27.76 \pm 2.8^{\mathrm{d}}$ & $40.61 \pm 6.26^{\mathrm{c}}$ \\
Ethyl acetate Musa sapeintum & $56.16 \pm 6.5^{\mathrm{c}}$ & $52.73 \pm 8.49^{\mathrm{b}}$ \\
Ethyl acetate Musa cavendish & $39.46 \pm 2.39^{\mathrm{d}}$ & $83.59 \pm 9.7^{\mathrm{a}}$ \\
Methanol Musa sapeintum & $80.95 \pm 6.38^{\mathrm{a}}$ & $77.71 \pm 5.47^{\mathrm{a}}$ \\
Methanol ex Musa cavendish & $71.15 \pm 7.18^{\mathrm{b}}$ & $77.41 \pm 10.4^{\mathrm{a}}$ \\
Water ex Musa sapeintum & $27.37 \pm 2.77^{\mathrm{d}}$ & $27.8 \pm 2.3^{\mathrm{d}}$ \\
Water ex Musa cavendish & $42.98 \pm 5.5^{\mathrm{d}}$ & $36.58 \pm 2.7^{\mathrm{cd}}$ \\
\hline
\end{tabular}

${ }^{\mathrm{a}-\mathrm{d}}$ Siguificut values

was chosen as the reference antioxidant in this study. The DPPH radical contains an odd electron which is responsible for the absorbance at $517 \mathrm{~nm}$ and also for a visible deep purple color. The decolourisation of the purple reaction solution is stoichiometric with respect to number of electrons donated by antioxidant compounds $^{[37]}$. Ascorbic acid as standard test has strongest radical scavenging activity $\left(98.16^{\mathrm{a}} \pm 3.5\right)$ but in extracts methanolic extract has the strongest radical scavenging activity $\left(87.36 \pm 0^{\mathrm{a}}\right.$ and $\left.85.97 \pm 4.6^{\mathrm{a}} \%\right)$ in Musa sapeintum and Musa cavandish peel compared to other successive extracts followed by Hexane extract and ethyl acetate, aqueous extract. These results are in agreement with ${ }^{[38]}$ who found the extracts prepared from ethanol had the most potent antioxidant activity whereas the extracts prepared from the solvent hexane displayed poor or moderate DPPH and FRAP scavenging activity. Among the tested extracts, peels extracted with ethanol exhibited potent antioxidant activity on DPPH with the lowest IC50 value calculated forthe ethanol extract $\left(19.10 \mu \mathrm{g} \mathrm{mL}^{-1}\right)^{[39]}$ who found that the banana peel extracts extracted with methanol demonstrated the highest percentage of DPPH radical scavenging.

Values represent mean $\pm \mathrm{SD}$ of 3 replicates; Total phenols was expressed as mg gallic acid equivalents/g for successive extract and dry tissue, flavonoids was expressed as mg querectine equivalents/g for successive extract and dry tissue; Mean followed by a common letter are not significantly different at the $5 \%$ level by CoStat.

Data in Table 6 Shown the total phenolic and total flavonoids effect of different successive extracts of Banana peel Musa sapeintum and Musa cavandish methanolic extract have higher total phenol $\left(80.95 \pm 6.38^{\mathrm{a}}\right.$ and $\left.71.15 \pm 7.18^{\mathrm{b}}\right)$, Total flavonoid $\left(77.71 \pm 5.47^{\mathrm{a}}\right.$ and $\left.77.41 \pm 10.4^{\mathrm{a}}\right)$. The ethyl acetate extract has high concentration of flavonoid in Musa cavandish $83.59 \pm 9.7^{\mathrm{a}} \mathrm{mg} \mathrm{g}^{-1[39]}$ who found thatin banana peel, TF varied from $467-756 \mathrm{mg}$ of catechin $/ 100 \mathrm{~g} \mathrm{dw}$. Someya et $a l .{ }^{[38]}$ reported that the main flavonoid compound in banana peel is gallocatechin (158 mg/100 $\mathrm{g} \mathrm{dw})$, although, TF values are less than that obtained in the present study, there are other flavonoids in banana peel such as catechin and epicatechin that could increase,
Table 7: Phenolic compound contents in Musa sapeintum and Musa cavendish

\begin{tabular}{lcc}
\hline Phenolic compound $(\mathrm{mg} / 100 \mathrm{~g})$ & Musa sapeintum & Musa cavandish \\
\hline Pyrogallo & 31.98 & 63.98 \\
Gallic acid & 0.58 & 3.32 \\
4-amino-benzoic & 0.44 & 0.98 \\
Protocatchoic acid & 1.22 & 3.09 \\
Catechein & 21.55 & 16.32 \\
Catechol & 0.32 & 2.32 \\
Chlorogenic & 1.05 & 5.24 \\
Epicatechein & 1.38 & 1.40 \\
P-OH-benzoic & 4.65 & 4.37 \\
Caffeic acid & 0.49 & 0.31 \\
Vanillic & 2.94 & 4.46 \\
P-coumaric & 0.44 & 0.85 \\
Ferulic & 2.17 & 1.89 \\
Iso-ferulic & 0.48 & 0.88 \\
E-vanilic & 19.60 & 7.23 \\
Ellagic & 5.57 & 1.48 \\
Benzoic & 1.62 & 1.58 \\
3, 4, 5-methoxy-cinnamic & 2.16 & 0.42 \\
Coumarin & 1.82 & 0.40 \\
Salycilic & 25.53 & 1.13 \\
Cinnamic & 2.95 & 0.06 \\
Caffeine & & 1.10 \\
Alpha-coumaric & & 0.32 \\
\hline
\end{tabular}

Also that, the flavonoid content showed higher content in methanolic extracts (as $\mathrm{mg} \mathrm{g}^{-1}$ Quercetine). Similar to the totalphenolic content, antioxidant activity of the extracts also varied with polarities of solvents. Similar findings were reported by Sulaiman et al. ${ }^{[40]}$ that found that the antioxidant activity exhibited by banana extracts is significantly affected by the solvents used for extraction.

Phenolic compound contents (mg/100 g) of Musa sapeintum and Musa cavandish peel, methanolic extract are shown in Table 7 . The results show the presence of pyrogallol (31.98 and 63.98) catechein (21.55 and 16.33), gallic (0.58 and 3.22), vanillic (2.94 and 4.46) ellagic (5.57 and 1.48), protocatchoic (1.22 and 3.09) and catechein (21.55 and 16.32), E-vanilic (19.6 and 7.23) salycilic (25.53 and 1.13) in Musa sapeintum and Musa cavandish peel methanolic extract, respectively.

The total phenol and flavonoid content of different banana peels extracts are shown in Table 8 and 9 . From the results, it is inferred that methanolic extract showed higher phenol content compared to other extracts which could be related to its antioxidant potential. content of Musa sapeintum and Musa cavendish (as $\mathrm{mg} \mathrm{g}^{-1}$ gallic acid). It is clear that methanolic extract represents the high content of Musa sapeintum and Musa cavendish $\left(80.95 \pm 6.38^{\mathrm{a}}\right.$ $\left.\mathrm{mg} \mathrm{g}^{-1}\right)$ and $\left(71.15 \pm 7.18 \mathrm{~b} \mathrm{mg} \mathrm{g}^{-1}\right)$ respectively., followed by ethyl acetate extract $\left(56.16 \pm 6.5^{\mathrm{c}} \mathrm{mg} \mathrm{g}^{-1}\right)$ and $\left(39.46 \pm 2.39^{\mathrm{d}} \mathrm{mg} \mathrm{g}^{-1}\right)$ and water extract $\left(27.37 \pm 2.77^{\mathrm{d}}\right.$ $\left.\mathrm{mg} \mathrm{g}^{-1}\right)$ and $\left(42.98 \pm 5.5^{\mathrm{d}} \mathrm{mg} \mathrm{g}^{-1}\right)$ in Musa sapeintum and Musa cavendish, respectively (Table 10).

\section{Antimicrobial}

In case antibacterial: Various extracts were selected according to polarization and efeect of this extracts 
Res. J. Biol. Sci., 15 (2): 40-52, 2020

Table 8: Phenolic compound contents in Musa sapeintum and Musa cavendish extracts

\begin{tabular}{|c|c|c|c|c|c|c|c|c|}
\hline Phenolic compound & Hexane 1 & Ethyl acetate 1 & Methanol 1 & Water 1 & Hexane 2 & Ethyl acetate 2 & Methanol 2 & Water 2 \\
\hline Pyrogallo & 9.69 & 36.79 & 584.67 & 209.77 & 15.48 & 139.32 & 739.42 & 98.41 \\
\hline Gallic acid & 0.27 & 9.63 & 21.62 & 4.23 & 0.7 & 29.01 & 32.19 & 9.04 \\
\hline 4-amino-benzoic & 0.07 & 5.65 & 2.8 & 2.44 & 0.33 & 2.5 & 2.4 & 1.39 \\
\hline Protocatchoic acid & 0.56 & 13.04 & 17.68 & 16.94 & 3.45 & 28.55 & 51.55 & 7.74 \\
\hline Catechein & 0.45 & 61 & 23.99 & 20.39 & 2.16 & 49.81 & 36.95 & 13.41 \\
\hline Catechol & 1.03 & 135.83 & 56.56 & 82.89 & 6.73 & 17.58 & 84.2 & 61.7 \\
\hline Chlorogenic & - & 6.55 & - & 41.73 & - & - & - & 7 \\
\hline Epicatechein & 0.96 & 3.71 & 9.24 & 73.23 & 7.33 & 11.46 & 9.77 & 10.44 \\
\hline P-OH-benzoic & 0.88 & 4.87 & 43.59 & & 4.84 & 35.21 & 22.13 & 4.05 \\
\hline Caffeic acid & 0.66 & 7.06 & 5.45 & 4.74 & & 37.55 & 3.79 & 0.95 \\
\hline Vanillic & 1.97 & 5.9 & & & 6.42 & - & 26.13 & 3.45 \\
\hline P-coumaric & 0.15 & 8.46 & 6.22 & 8.97 & 0.84 & 14.72 & 5.1 & 1.04 \\
\hline Ferulic & 0.39 & 12.5 & 5.22 & 14.44 & 1.01 & 29.34 & 2.76 & 2.42 \\
\hline Iso-ferulic & - & 3.54 & 0.55 & & 0.84 & 2.69 & 2.35 & 1.48 \\
\hline E-vanilic & 31.18 & 186.13 & 227.55 & 597.62 & 71.02 & 970.96 & 201.84 & 214.24 \\
\hline Ellagic & 21.13 & 238.14 & - & - & 120.51 & 998.94 & 296.52 & 61.38 \\
\hline Benzoic & 3.58 & 27.39 & 44.92 & - & 16.1 & - & 39.33 & 17.19 \\
\hline 3,4,5-methoxy-cinnamic & 1.67 & 7.13 & 9.4 & 19.52 & 3.98 & 39.83 & 14.71 & 3.63 \\
\hline Coumarin & 0.35 & 2.4 & 1.98 & & 2.06 & 7.45 & 2.21 & 1.29 \\
\hline Salycilic & 1.7 & 15.56 & 7.27 & 10.07 & 10.58 & 22.47 & 60.75 & 2.67 \\
\hline Cinnamic & 0.08 & 1.23 & 0.48 & 1.48 & 0.22 & 2.49 & 0.27 & 0.23 \\
\hline Caffeine & - & 3.67 & - & - & - & 22.22 & 5.1 & 1.81 \\
\hline Alpha-coumaric & 0.37 & - & 1.65 & 4.32 & - & - & 2.59 & - \\
\hline
\end{tabular}

Table 9: Flavonoid compound contents in Musa spp

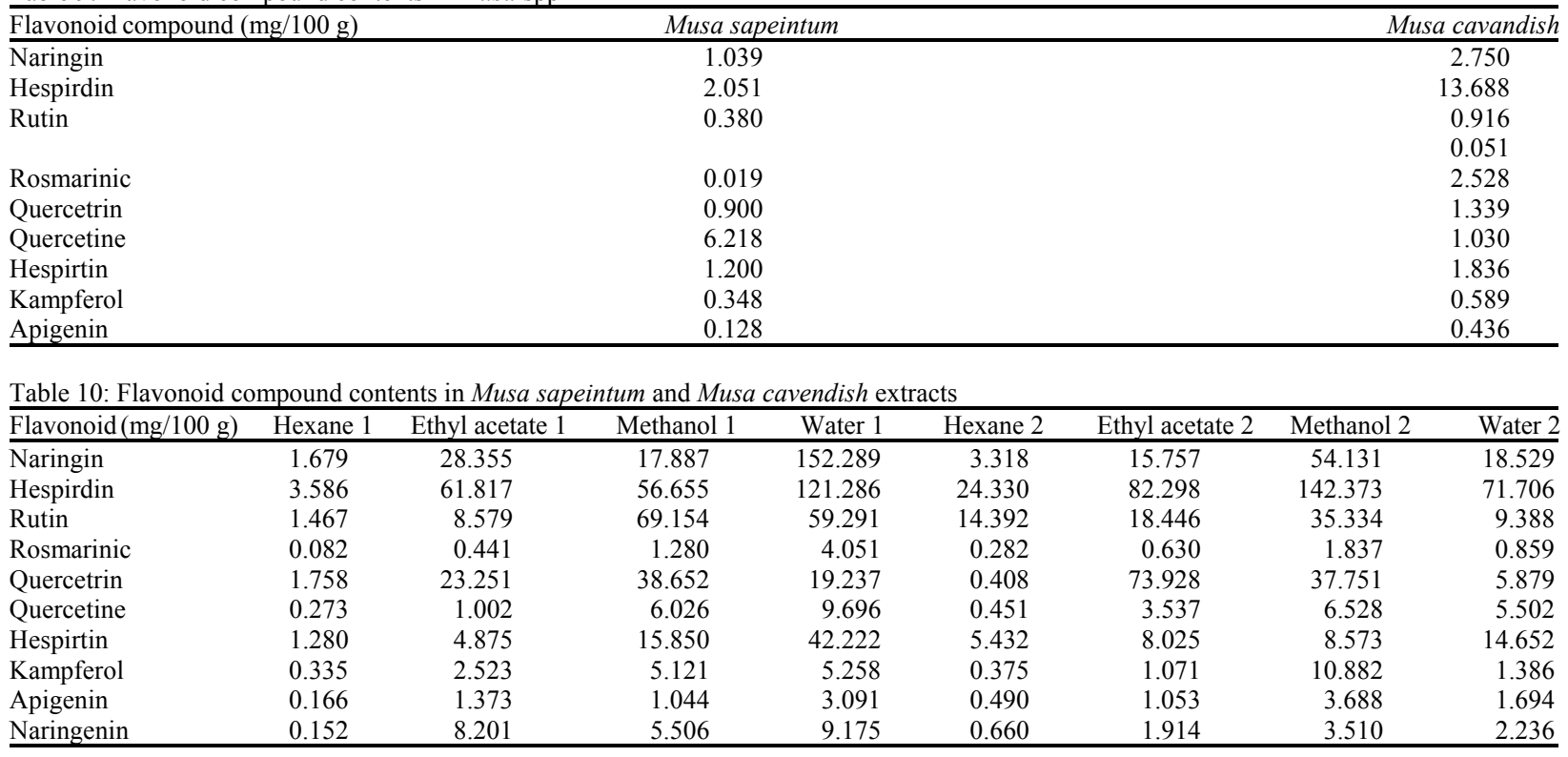

on two species of banana peel Musa sapeintum and Musa cavandish two of them were given a stronger effect and two were given a lower effect with two banana species. The extracts that are given as a strong ereffect are them ethanolic and ethyl acetate extract. Since, the methanolic extract contains effective ingredients that dissolve completely in the mixture, the lower concentration of this extract is given a higher positive result. While the opposite is the case with the use of ethyl acetate extract (Fig. 4-7).

Where, the methanolic extract is given a positive result in the four strains higher result with bacillus cereus followed by $E$. coli followed by Salmonella typhimurium and Staphylococcus aureus. And low effect in E. coli when compared with other bacteria. Methanolic extract has higher effect on fungi (Asprgilus niger and Fusarium oxysporum) While in the case of ethyl acetate extract, it is given a positive result with the positive bacteria of gram and the negative bacteria of the gram and the positive bacteria of gram there is a difference between them where Bacillus cereus is given with the lowest concentrations while Staphylococcus aureus given with the highest concentration and Salmonella typhimurium given effect with lower concentration and $E$. coli not give any effect with ethyl acetate extract. Ethyl acetate extract has higher effect on fungi (Asprgilus niger and Fusarium 
Res. J. Biol. Sci., 15 (2): 40-52, 2020
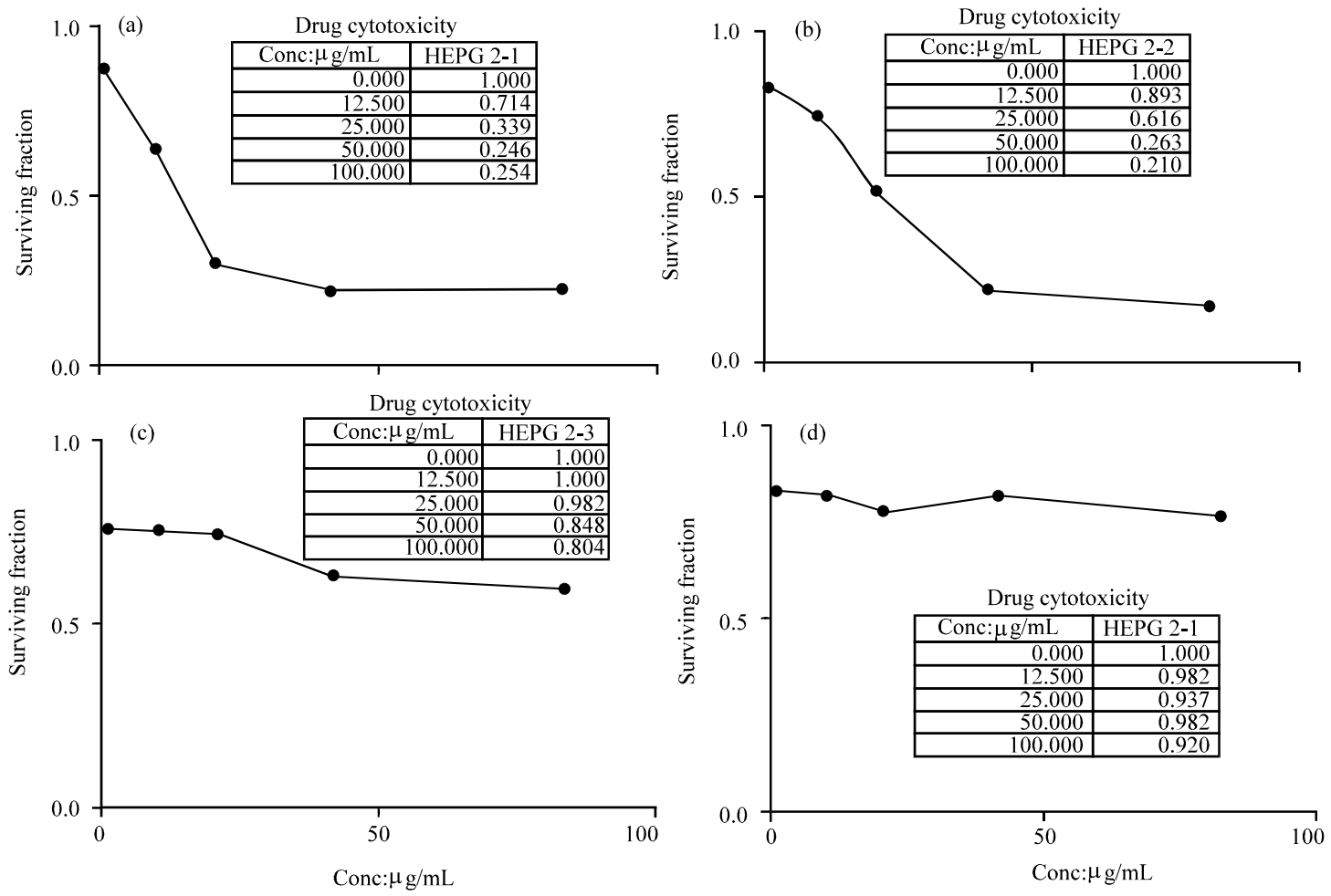

Fig. 4(a-d): Anti Hepatic cancer (HEP G2) of Musa sapentum: a) HEP G2-1; b) HEP G2-2; c) HEP G2-3 and d) HEP G2-4
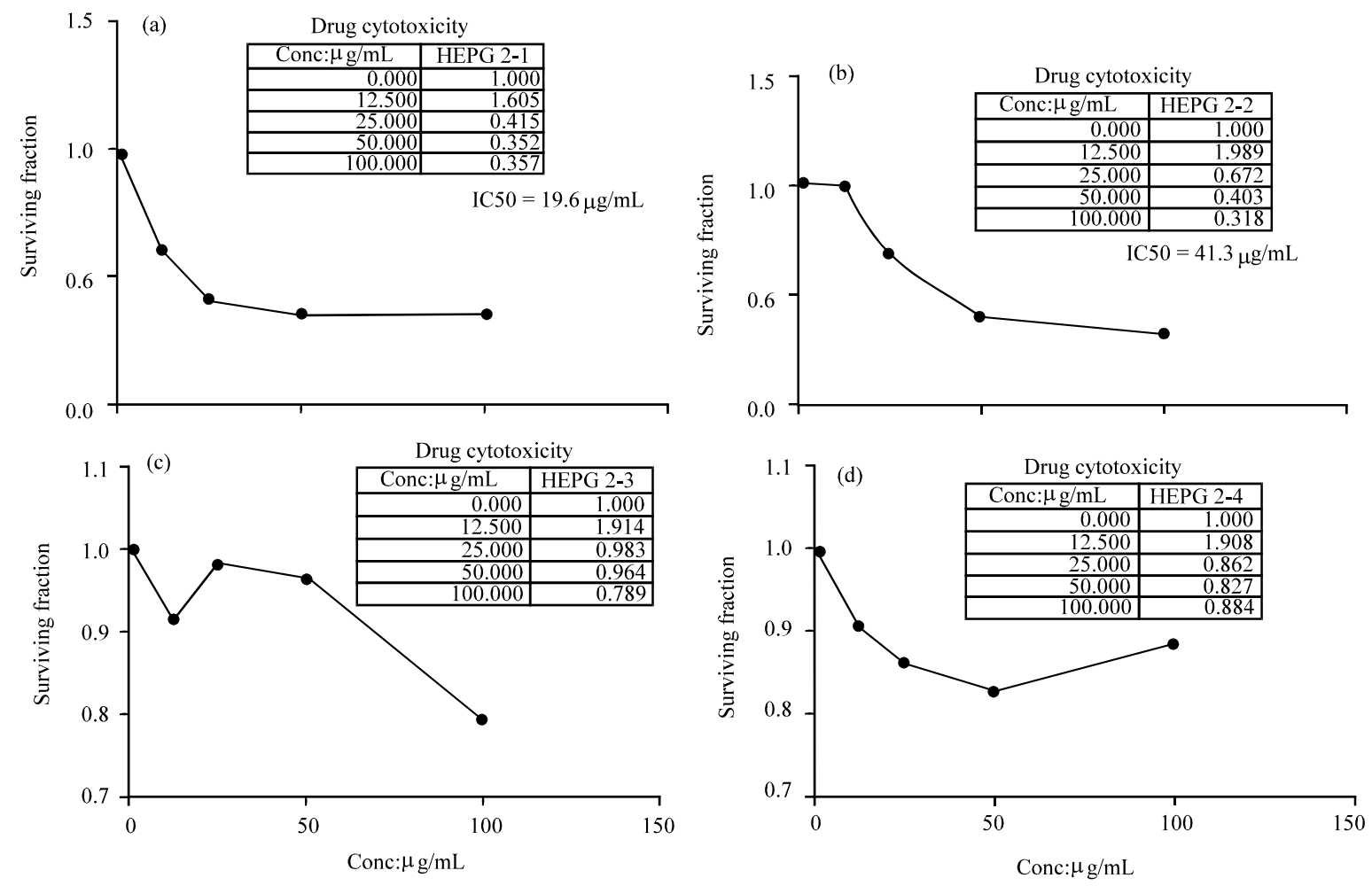

Fig. 5(a-d): Anti colonic cancer (HCT) of Musa sapentum: a) HCT-1; b) HCT; c) HCT-3 and d) HCT-4 
Res. J. Biol. Sci., 15 (2): 40-52, 2020
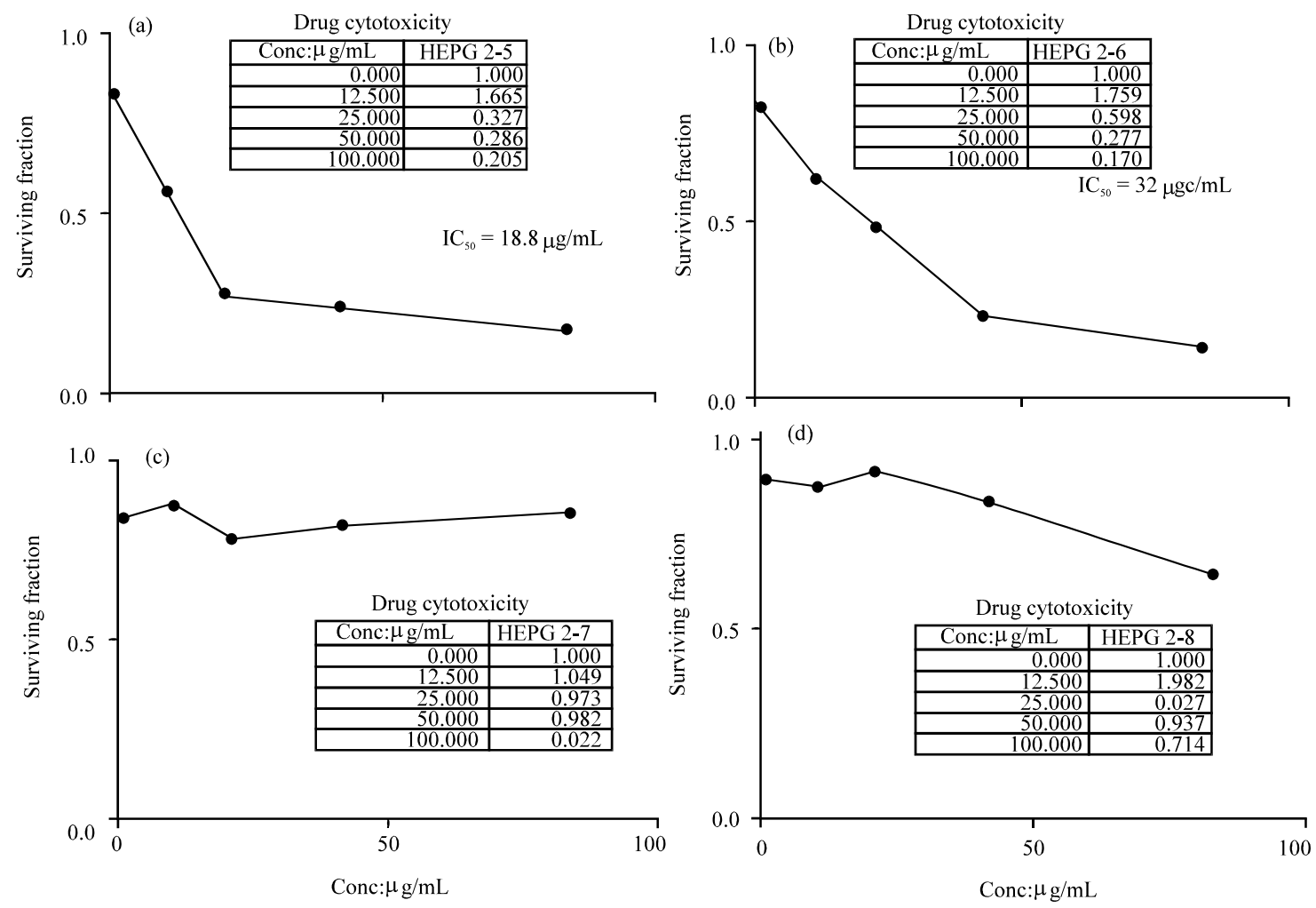

Fig. 6(a-d): Anti cancer (HEP G2) of Musa cavendish: a) HEP G2-5; b) HEP G2-6; c) HEP G2-7 and d) HEP G2-8
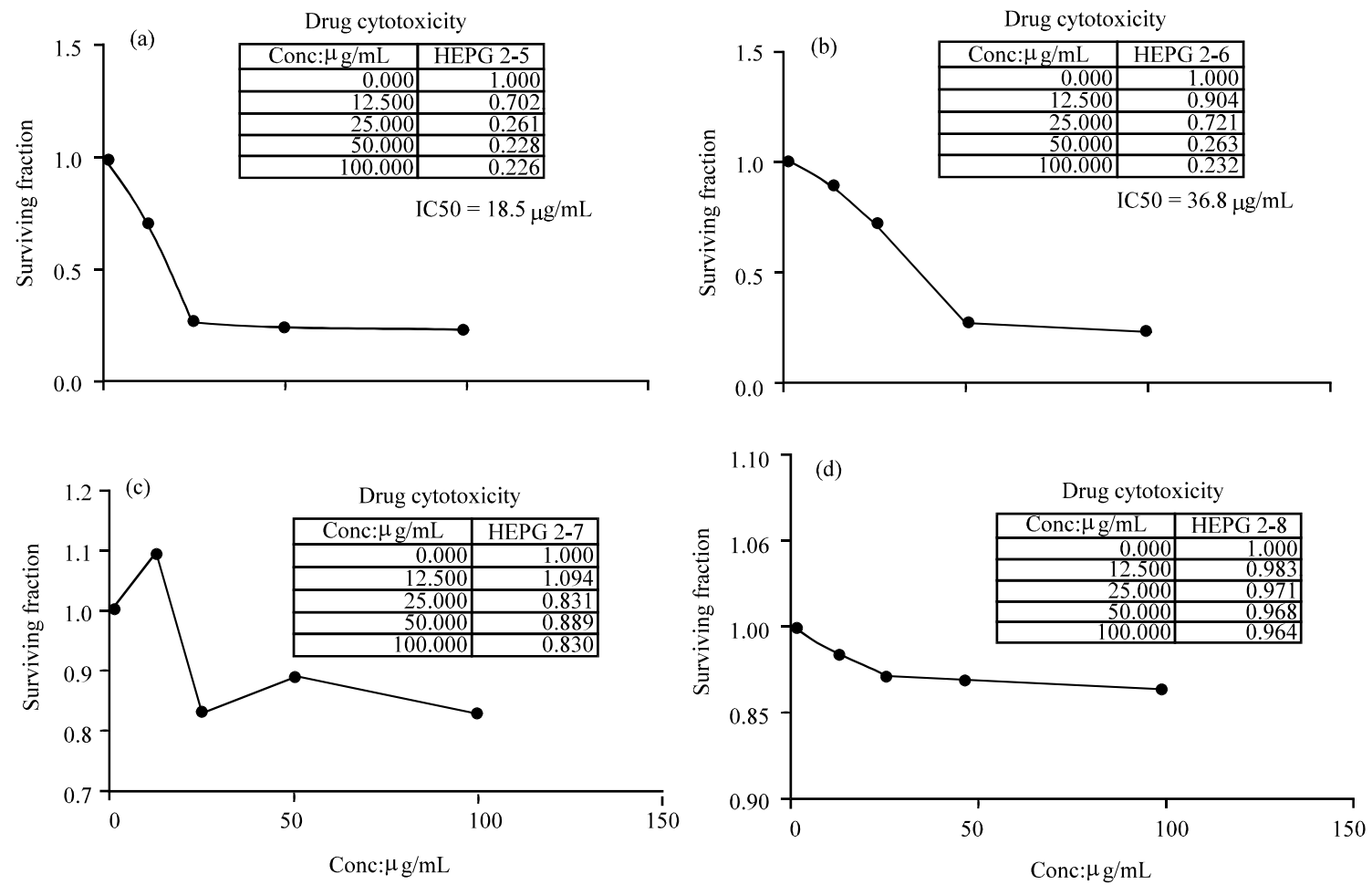

Fig. 7(a-d): Anti colonic cancer (HCT) of Musa cavendish: a) HCT-5; b) HCT-6; c) HCT-7 and d) HCT-8 
oxysporum). Hexane extract and water extract have moderate effect with high concentration (256 and $512 \mathrm{mg} \mathrm{mL}^{-1}$ ) in positive gram and fungi but have not detected with negative gram bacteria. This result in agreement with $^{[41]}$ who found the banana inflorescence extracted with 80 and $100 \%$ methanol gave the strongest antibacterial activity against all tested bacteria. The addition of water increase the polarity of the extracting solvent makes it more selective and more antibacterial compounds from the samples becoming soluble ${ }^{[42]}$. However, the addition of more water to alcohol ratio also, increases the retention of highly polar non-bioactive polysaccharides which explain the reduction of antibacterial activity on Gram negative bacteria ${ }^{[43]}$. Ethyl acetate extract showed higher activity than the ethanolic extract both in case of peel as well as pulp $24 \mathrm{~mm}$ of clear inhibition zone against Gram positive bacteria $S$. aureus. In fact, high antibacterial activity against all test organisms was observed with ethyl acetate extract of peel and pulp and zone diameters ranged from 12.5-24 mm antibacterial activity obtained in this study varied with solvents used for extraction. Ethyl acetate extracts showed best antibacterial activity against both Gram positive and Gram negative bacteria with Gram positive slightly more susceptible to the extracts than Gram negative bacteria. Hexane extract of either part did not show any antibacterial activity against any of the bacteria. Some studies have reported similar findings ${ }^{[44]}$ and this difference in sensitivity could be attributed to different morphological ${ }^{[44]}$. Jalani et al. ${ }^{[45]}$ found that the antibacterial activity of different extracts of banana pulps were analyzed in vitro against Gram positive and negative bacteria by disc diffusion method. The aqueous extract of all types of banana pulp displayed no zone of inhibition indicating no antibacterial activity. Acetone and methanol extracts of all banana pulps exhibited antibacterial activity only against $P$. aeruginos $a$ and $E$. coli at $10 \mathrm{mg} / \mathrm{disc}$. The highest antibacterial activity was observed with methanol extract of banana pulps against $E$. coli with $8.5 \mathrm{~mm}$ zone of inhibition. Mokbel and Hashinaga ${ }^{[46]}$ found that EtoAc extract of green banana peel recorded significant antimicrobial activities while yellow peel extracts recorded low activity and no activity was recorded to $\mathrm{CHCl}_{3}$ and water extracts as measured by paper disk methods. Ehiowemwenguan et al. ${ }^{[47]}$ can be conclude that ethanol extract of Musa sapientum peels had significant in vitro broad spectrum antimicrobial activity. Thus, extracts from the plant can be used to control infections caused by Salmonella typhi, Escherichia coli, Klebsiella pneumoniae and Staphylococcus aureus. Opportunistic infections such as bronchopneumonia, bacterial endocarditis and meningitis caused by Micrococcus spp. and Pseudomonas aeruginosa will also, find treatment with the extracts of this medicinal peel. El Zawawy ${ }^{[48]}$ banana extracts, high antibacterial activity was recorded for S. aureus.

Cytotoxicity effects: Banana extracts were tested for the irability to inhibit the growth of HCT and HEP-G ${ }_{2}$, tumorcell lines (Table 11-13). The extracts showing $>80 \%$

Table 11: Antimicrobial activity of Musa sapeintum peel extracts using various extraction solvents

\begin{tabular}{|c|c|c|c|c|c|c|c|}
\hline \multirow[b]{2}{*}{ EEP concentration $(\mathrm{mg} / \mathrm{mL})$} & \multirow[b]{2}{*}{ Solvent } & \multicolumn{6}{|c|}{ Diameter of inhibition zone (mm) } \\
\hline & & $\mathrm{BC}$ & SA & ST & E. coli & $\mathrm{AN}$ & $\mathrm{FO}$ \\
\hline \multirow[t]{4}{*}{ From 2-16 } & Hexane & ND & ND & ND & ND & ND & ND \\
\hline & EtoAc & ND & ND & ND & ND & ND & ND \\
\hline & $\mathrm{MeOH}$ & ND & ND & ND & ND & ND & ND \\
\hline & $\mathrm{H}_{2} \mathrm{O}$ & ND & ND & ND & ND & ND & ND \\
\hline \multirow[t]{4}{*}{32} & Hexane & ND & ND & ND & ND & ND & ND \\
\hline & EtoAc & $3.39 \pm 0.26^{\mathrm{a}}$ & ND & ND & ND & ND & ND \\
\hline & $\mathrm{MeOH}$ & $7.21 \pm 0.4^{\mathrm{a}}$ & ND & $6.12 \pm 0.5^{\mathrm{a}}$ & ND & $5.63 \pm 0.4^{\mathrm{b}}$ & ND \\
\hline & $\mathrm{H}_{2} \mathrm{O}$ & ND & $6.78 \pm 0.54^{\mathrm{a}}$ & ND & ND & ND & ND \\
\hline \multirow[t]{4}{*}{64} & Hexane & ND & ND & ND & ND & ND & ND \\
\hline & EtoAc & $5.22 \pm 0.24^{\mathrm{a}}$ & ND & ND & ND & $5.39 \pm 0.26^{\mathrm{a}}$ & ND \\
\hline & $\mathrm{MeOH}$ & $12.53 \pm 0.2^{\mathrm{a}}$ & ND & $10.63 \pm 0.33^{\mathrm{a}}$ & ND & $8.18 \pm 0.23^{b}$ & $6.63 \pm 0.22^{\mathrm{b}}$ \\
\hline & $\mathrm{H}_{2} \mathrm{O}$ & ND & ND & ND & ND & ND & ND \\
\hline \multirow[t]{4}{*}{128} & Hexane & ND & ND & ND & ND & ND & ND \\
\hline & EtoAc & $8.86 \pm 0.16^{\mathrm{a}}$ & ND & $6.39 \pm 0.26^{\mathrm{b}}$ & ND & $8.53 \pm 0.62^{\mathrm{a}}$ & $7.73 \pm 0.82^{\mathrm{a}}$ \\
\hline & $\mathrm{MeOH}$ & $20.53 \pm 0.3^{c}$ & $5.53 \pm 0.62^{b}$ & $18.53 \pm 0.62^{\mathrm{d}}$ & $3.83 \pm 0.19^{\mathrm{b}}$ & $13.13 \pm 0.12^{\mathrm{b}}$ & $10.63 \pm 0.8^{\mathrm{a}}$ \\
\hline & $\mathrm{H}_{2} \mathrm{O}$ & $3.43 \pm 0.25^{\mathrm{a}}$ & ND & $4.34 \pm 0.86^{\mathrm{a}}$ & ND & $5.04 \pm 0.16^{\mathrm{a}}$ & ND \\
\hline \multirow[t]{4}{*}{256} & Hexane & $6.52 \pm 0.24^{\mathrm{b}}$ & $6.38 \pm 0.25^{\mathrm{b}}$ & ND & ND & $7.53 \pm 0.62^{\mathrm{a}}$ & $6.45 \pm 0.45^{\mathrm{b}}$ \\
\hline & EtoAc & $10.24 \pm 0.236^{\mathrm{a}}$ & $6.47 \pm 0.72^{\mathrm{a}}$ & $10.39 \pm 0.26^{\mathrm{a}}$ & $8.31 \pm 0.22^{\mathrm{a}}$ & $16.83 \pm 0.52^{\mathrm{a}}$ & $12.44 \pm 0.72^{\mathrm{a}}$ \\
\hline & $\mathrm{MeOH}$ & $26.31 \pm 0.37^{\mathrm{a}}$ & $8.53 \pm 0.42^{\mathrm{a}}$ & $25.43 \pm 0.82 \mathrm{a}$ & $6.13 \pm 0.12^{\mathrm{b}}$ & $22.53 \pm 0.18^{a}$ & $15.23 \pm 0.4^{\mathrm{a}}$ \\
\hline & $\mathrm{H}_{2} \mathrm{O}$ & $7.76 \pm 0.36^{\mathrm{d}}$ & ND & $8.34 \pm 0.65^{\mathrm{a}}$ & ND & $8.93 \pm 0.7^{\mathrm{a}}$ & $4.76 \pm 0.86^{\mathrm{a}}$ \\
\hline \multirow[t]{4}{*}{512} & Hexane & $11.72 \pm 0.24^{\mathrm{b}}$ & $8.38 \pm 0.25^{b}$ & ND & ND & $11.53 \pm 0.62^{\mathrm{c}}$ & $10.45 \pm 0.45^{\mathrm{b}}$ \\
\hline & EtoAc & $17.64 \pm 0.36^{b}$ & $9.47 \pm 0.72^{\mathrm{a}}$ & $17.53 \pm 0.62^{\mathrm{a}}$ & ND & $26.23 \pm 0.43^{\mathrm{a}}$ & $22.83 \pm 0.52^{\mathrm{a}}$ \\
\hline & $\mathrm{MeOH}$ & $35.31 \pm 0.37^{\mathrm{a}}$ & $8.53 \pm 0.62^{\mathrm{a}}$ & $33.23 \pm 0.26^{\mathrm{a}}$ & $9.11 \pm 0.36^{\mathrm{c}}$ & $27.58 \pm 0.3 \mathrm{a}$ & $19.53 \pm 0.3^{\mathrm{a}}$ \\
\hline & $\mathrm{H}_{2} \mathrm{O}$ & $12.44 \pm 0.2^{\mathrm{a}}$ & ND & $14.53 \pm 0.3^{\mathrm{d}}$ & ND & $14.93 \pm 0.6 b c$ & $9.22 \pm 0.5 b c$ \\
\hline
\end{tabular}

Data represent the means $\pm \mathrm{SD}(\mathrm{n}=3)$ including the well diameter, ${ }^{\mathrm{a}-\mathrm{c}}$ Subscripts represent significance differences between extraction solvents at $\mathrm{p}<0.05$ 'ND' Not Detected. $\mathrm{H}_{2} \mathrm{O}$ : Deionized water, MeOH: Methanol, EtoAc: Ethyl Acetate, SA: Staphylococcus aureus (gram+), BC: Bacillus cereus (gram+), ST: Salmonella typhimurium (gram-), E coli: Escherichia coli (gram-), Fo: Fusarium oxysporum (Fungi), AN: Asprgilus niger (Fungi). 
Res. J. Biol. Sci., 15 (2): 40-52, 2020

Table 12: Antimicrobial activity of Musa sapeintum peel extracts using various extraction solvents

\begin{tabular}{|c|c|c|c|c|c|c|c|}
\hline \multirow[b]{2}{*}{ EEP concentration $(\mathrm{mg} / \mathrm{mL})$} & \multicolumn{7}{|c|}{ Diameter of inhibition zone (mm) } \\
\hline & Solvent & $\mathrm{BC}$ & SA & ST & E. coli & $\mathrm{AN}$ & FO \\
\hline \multirow[t]{4}{*}{ From 2-16 } & Hexane & ND & ND & ND & ND & ND & ND \\
\hline & EtoAc & ND & ND & ND & ND & ND & ND \\
\hline & $\mathrm{MeOH}$ & ND & ND & ND & ND & ND & ND \\
\hline & $\mathrm{H}_{2} \mathrm{O}$ & ND & ND & ND & ND & ND & ND \\
\hline \multirow[t]{4}{*}{32} & Hexane & ND & ND & ND & ND & ND & ND \\
\hline & EtoAc & $3.39 \pm 0.26^{\mathrm{a}}$ & ND & ND & ND & $\mathrm{ND}$ & ND \\
\hline & $\mathrm{MeOH}$ & $8.21 \pm 0.4^{\mathrm{a}}$ & $5.63 \pm 0.7^{\mathrm{a}}$ & $6.12 \pm 0.5^{\mathrm{a}}$ & ND & $5.63 \pm 0.4^{\mathrm{b}}$ & ND \\
\hline & $\mathrm{H}_{2} \mathrm{O}$ & ND & $6.78 \pm 0.54^{\mathrm{a}}$ & ND & ND & ND & ND \\
\hline \multirow[t]{4}{*}{64} & Hexane & ND & ND & ND & ND & ND & ND \\
\hline & EtoAc & $4.22 \pm 0.24^{\mathrm{a}}$ & ND & ND & ND & ND & ND \\
\hline & $\mathrm{MeOH}$ & $13.53 \pm 0.2^{\mathrm{a}}$ & $9.43 \pm 0.82^{\mathrm{a}}$ & $10.63 \pm 0.33^{\mathrm{a}}$ & ND & $8.18 \pm 0.23^{b}$ & $6.63 \pm 0.22^{b}$ \\
\hline & $\mathrm{H}_{2} \mathrm{O}$ & ND & ND & ND & ND & ND & ND \\
\hline \multirow[t]{4}{*}{128} & Hexane & ND & ND & ND & ND & ND & ND \\
\hline & EtoAc & $7.86 \pm 0.16^{\mathrm{a}}$ & ND & $5.59 \pm 0.96^{\mathrm{a}}$ & ND & $5.95 \pm 0.54^{\mathrm{a}}$ & $3.73 \pm 0.82^{\mathrm{a}}$ \\
\hline & $\mathrm{MeOH}$ & $20.53 \pm 0.3^{c}$ & $12.63 \pm 0.72^{\mathrm{b}}$ & $22.56 \pm 0.42^{\mathrm{d}}$ & $3.33 \pm 0.59^{\mathrm{b}}$ & $13.13 \pm 0.12^{\mathrm{b}}$ & $8.66 \pm 0.8^{\mathrm{a}}$ \\
\hline & $\mathrm{H}_{2} \mathrm{O}$ & ND & ND & $5.32 \pm 0.96^{\mathrm{a}}$ & ND & $5.04 \pm 0.16^{\mathrm{a}}$ & ND \\
\hline \multirow[t]{4}{*}{256} & Hexane & $7.82 \pm 0.88^{c}$ & ND & $\mathrm{ND}$ & ND & $5.53 \pm 0.62^{\mathrm{c}}$ & $3.72 \pm 0.65^{\mathrm{b}}$ \\
\hline & EtoAc & $10.24 \pm 0.236^{\mathrm{a}}$ & $4.67 \pm 0.55^{\mathrm{a}}$ & $10.39 \pm 0.263^{\mathrm{a}}$ & $5.71 \pm 0.66^{\mathrm{a}}$ & $9.73 \pm 0.43^{b}$ & $6.44 \pm 0.72^{\mathrm{a}}$ \\
\hline & $\mathrm{MeOH}$ & $25.61 \pm 0.39^{\mathrm{a}}$ & $17.63 \pm 067^{\mathrm{a}}$ & $0.53 \pm 0.92^{\mathrm{a}}$ & $7.18 \pm 0.32^{\mathrm{b}}$ & $20.13 \pm 0.68^{\mathrm{d}}$ & $12.26 \pm 0.8^{\mathrm{a}}$ \\
\hline & $\mathrm{H}_{2} \mathrm{O}$ & $6.76 \pm 0.36^{\mathrm{d}}$ & ND & $9.38 \pm 0.66^{\mathrm{a}}$ & ND & $10.83 \pm 0.7^{\mathrm{a}}$ & $5.76 \pm 0.46^{\mathrm{a}}$ \\
\hline \multirow[t]{4}{*}{512} & Hexane & $10.55 \pm 0.34^{\mathrm{a}}$ & $5.38 \pm 0.25^{\mathrm{b}}$ & ND & ND & $9.43 \pm 0.22^{\mathrm{d}}$ & $6.43 \pm 0.94^{\mathrm{b}}$ \\
\hline & EtoAc & $13.33 \pm 0.32^{\mathrm{b}}$ & $8.56 \pm 0.42^{\mathrm{a}}$ & $12.73 \pm 0.62^{\mathrm{d}}$ & $9.48 \pm 0.65^{\mathrm{c}}$ & $6.43 \pm 0.94^{b}$ & $11.73 \pm 0.82^{\circ}$ \\
\hline & $\mathrm{MeOH}$ & $33.21 \pm 0.45^{\mathrm{a}}$ & $21.58 \pm 0.97^{\mathrm{a}}$ & $36.27 \pm 0.67^{\mathrm{a}}$ & & $25.52 \pm 0.34 \mathrm{a}$ & $16.83 \pm 0.34^{\mathrm{a}}$ \\
\hline & $\mathrm{H}_{2} \mathrm{O}$ & $11.46 \pm 0.33^{\mathrm{a}}$ & ND & $13.34 \pm 0.5^{\mathrm{d}}$ & ND & $14.93 \pm 0.6^{\mathrm{bc}}$ & $10.29 \pm 0.4^{\mathrm{d}}$ \\
\hline
\end{tabular}

Table 13: Cytotoxic effects of Musa sapientum and Musa cavendish extracts

\begin{tabular}{llll}
\hline $\mathrm{IC}_{50}$ & & & \\
\hline Banana verities & Solvent & $\mathrm{HCT}$ & HEP-G2 \\
\hline Musa sapeintum & Hexane & 19.6 & 19.7 \\
& EtoAc & 41.3 & 33 \\
& $\mathrm{MeOH}$ & $\mathrm{ND}$ & $\mathrm{ND}$ \\
& $\mathrm{H}_{2} \mathrm{O}$ & $\mathrm{ND}$ & $\mathrm{ND}$ \\
Musa cavendish & $\mathrm{Hexane}$ & 18.8 & 18.5 \\
& EtoAc & 32 & 36.8 \\
& $\mathrm{MeOH}$ & $\mathrm{ND}$ & $\mathrm{ND}$ \\
& $\mathrm{H}_{2} \mathrm{O}$ & $\mathrm{ND}$ & $\mathrm{ND}$ \\
\hline
\end{tabular}

inhibition of cell proliferation were considered to be active extracts. Hexane extracts of banana peel exhibited the highest cytotoxicity to wards HCT and $\mathrm{HEP}-\mathrm{G}_{2}$ with inhibition of 80.4 and 80.3 , respectively, $\mathrm{IC}_{50} 19.6$ and 19.7, respectively in Musas ape in tum, ethyl acetate extract have inhibition of 58.70 and 67, respectively, $\mathrm{IC}_{50} 41.3$ and 33, respectively in Musa sapeintum. Hexane extracts have (81.5 and 81.2, respectively), $\mathrm{IC}_{50} 18.5$ and 18.8 , respectively in Musa cavendish. Followed by ethyl acetate extracts have inhibition of (63.2 and 68, respectively), $\mathrm{IC}_{50} 36.8$ and 32, respectively in Musa cavendish. On other hand the water and methanolic extracts showed no antiproliferative effects against HCT and HEP-G $\mathrm{G}_{2}$. Most importantly, all banana extracts showed poor cytotoxicity against the normal cellline. The morphological alteration of the treated cancercells presented clear evidence of significant cytotoxicity of hexane banana extracts. Followed by ethyl acetate extract.

\section{CONCLUSION}

This result in agreement with Dahham et al. ${ }^{[38]}$ who found the cytotoxicity assay showed that the highly non-polar solvent extract (i.e., n-hexane extracts) had the highest cytotoxic activity among the extract stested. Among the 6 extracts, the hexane extract of banana peel had a strong cytotoxic effect on tested cancer cell lines. Our findings In contrast, all banana extracts were not cytotoxic to the normal cell line (HUVEC). However, the results of the antiangiogenic study showed that out of the six extracts from banana, only two showed a strong inhibitory effect $(>60 \%)$.

\section{REFERENCES}

01. Rahman, M.M. and S.M.H. Kabir, 2003. Banglapedia. 1st Edn., Asiatic Society of Bangladesh, Dhaka, Bangladesh, Pages: 403.

02. Alkarkhi, A.F.M., R. Saifullah, Y. Yong and M.E. Azhar, 2010. Physicochemical properties of banana peel flour as influenced by variety and stage of ripeness: Multivariate statistical analysis. Asian J. Food Agro Ind., 3: 349-362. 
03. Anonymous, 2015. Ministry of agriculture and land reclamation. American Refugee Committee, Minneapolis, Minnesota, USA.

04. Tchobanoglous, G., H. Theisen and S. Vigil, 1993. Integrated Solid Waste Management: Engineering Principles and Management Issues. 2nd Edn., McGraw-Hill, New York, ISBN-10: 0070632375, Pages: 992.

05. Emaga, T.H., R.H. Andrianaivo, B. Wathelet, J.T. Tchango and M. Paquot, 2007. Effects of the stage of maturation and varieties on the chemical composition of banana and plantain peels. Food Chem., 103: 590-600.

06. Arawande, J.O. and E.A. Komolafe, 2010. Antioxidative potentials of banana and plantain peel extracts on crude palm oil. Ethnobotanical Leafl., 14: 559-569.

07. Kanazawa, K. and H. Sakakibara, 2000. High content of dopamine, a strong antioxidant in cavendish banana. J. Agric. Food Chem., 48: 844-848.

08. Someya, S., Y. Yoshiki and K. Okubo, 2002. Antioxidant compounds from bananas (Musa cavendish). Food Chem., 79: 351-354.

09. Brooks, A.A., 2008. Ethanol production potential of local yeast strains isolated from ripe banana peels. Afr. J. Biotechnol., 7: 3749-3752.

10. Omojasola, P.F. and O.P. Jilani, 2009. Cellulase production by Trichoderma longi, Aspergillus niger and Saccharomyces cerevisae cultured on plantain peel. Res. J. Microbiol., 4: 64-74.

11. Ratule M.T., A. Osman, N. Saari and S.H. Ahmad, 2007. Microstructure of peel cell wall and selected physic-chemical characteristics of Berangan banana (Musacv. Berangan [AAA]) ripened at high temperature. Asia Pacific J. Mol. Biol. and Biotech., 15: 8-13.

12. Anhwange, B.A., T.J. Ugye and T.D. Nyiaatagher, 2009. Chemical composition of Musa sapientum (banana) peels. Electron. J. Environ. Agric. Food Chem., 8: 437-442.

13. Ghani, A., 2003. Medicinal Plants of Bangladesh with Chemical Constituents and Uses. 2nd Edn., Asiatic Society of Bangladesh, Dhaka, Bangladesh, Pages: 603.

14. Goulas, V. and G.A. Manganaris, 2012. Exploring the phytochemical content and the antioxidant potential of Citrus fruits grown in Cyprus. Food Chem., 131: $39-47$.

15. Mordi, R.C., A.E. Fadiaro, T.F. Owoeye, I.O. Olanrewaju and G.C. Uzoamaka et al., 2016. Identification by GC-MS of the components of oils of banana peels extract, phytochemical and antimicrobial analyses. Res. J. Phytochem., 10: $39-44$.
16. AOAC., 2005. Official Methods of Analysis of the Association of Official Analytical Chemist. 18th Edn., Horwitz William Publication, Washington, DC., USA.

17. Goupy, P., M. Hugues, P. Boivin and M.J. Amiot, 1999. Antioxidant composition and activity of barley (Hordeum vulgare) and malt extracts and of isolated phenolic compounds. J. Agric. Food Chem., 79: 1625-1634.

18. Mattila, P., J. Astola and J. Kumpulainen, 2000. Determination of flavonoids in plant material by HPLC with diode-array and electro-array detections. J. Agric. Food Chem., 48: 5834-5841.

19. AOAC., 2000. Official Methods of Analysis of AOAC International. 17th Edn., AOAC International, Gaitherburg, MD., USA., ISBN-13: 9780935584677 , Pages: 2200.

20. Vogel, A.I., 1975. A Text Book of Practical Organic Chemistry. 3rd Edn., ELBS Publisher, Londan, UK., Pages: 721.

21. Brand-Williams, W., M.E. Cuvelier and C. Berset, 1995. Use of a free radical method to evaluate antioxidant activity. LWT-Food Sci. Technol., 28: 25-30.

22. Singleton, V.L. and J.A. Rossi, 1965. Colorimetry of total phenolics with phosphomolybdicphosphotungstic acid reagents. Am. J. Enol. Viticult., 16: 144-158.

23. Hoslattmann, K. and M. Hoslattmann, 1982. Isolation Techniques for Flavonoid in the Flavonoid: Advances in Research. In: The Flavonoids Advances in Research, Haboran, J.B. and T.J. Mabry (Eds.). Springer, Berlin, Germany, ISBN:978-14899-2915-0, pp: 1-18.

24. Bauer, A.W., W.M. Kirby, J.C. Sherris and M. Turck, 1966. Antibiotic susceptibility testing by a standardized single disk method. Am. J. Clin. Pathol., 45: 493-496.

25. Cheesbrough, M., 2000. District Laboratory Practice in Tropical Countries Part 2. 1st Edn., Cambridge University Press, Cambridge, London, ISBN-13: 978-0521665452, pp: 434.

26. Skehan, P., R. Storeng, D. Scudiero, A. Monks and J. McMahon et al., 1990. New colorimetric cytotoxicity assay for anticancer-drug screening. J. Natl. Cancer Inst., 82: 1107-1112.

27. Waller, R.A. and D.B. Duncan, 1969. A bayes rule for the symmetric multiple comparisons problem. J. Am. Stat. Assoc., 64: 1484-1503.

28. Schmidt, M.M., R.C. Prestes, E.H. Kubota, G. Scapin and M.A. Mazutti, 2015. Evaluation of antioxidant activity of extracts of banana in florescences (Musa cavendishii). CyTA. J. Food, 13: 498-505. 
29. Yan, L., W.M. Fernando, M. Brennan, C.S. Brennan and V. Jayasena et al., 2016. Effect of extraction method and ripening stage on banana peel pigments. Intl. J. Food Sci. Technol., 51: 1449-1456.

30. Nagarajaiah, S.B. and J. Prakash, 2011. Chemical composition and antioxidant potential of peels from three varieties of banana. Asian J. Food Agro-Ind., 4: 31-46.

31. Gulizar, K. and Y. Sibel, 2011. Extracts using different extraction method-research gate. J. Agr. Food Chem., 47: 4638-4644.

32. Anhwange, B.A., 2008. Chemical composition of Musa sapientum (banana) peels. J. Food Technol., 6: 263-266.

33. Zafar, I.M., A. Saleha, M.M.E. Hoque and R.M. Sohel, 2011. Antimicrobial and cytotoxic properties of different extracts of Musa sapientum L. subsp. sylvestris. Int. Res. J. Pharm., 2: 62-65.

34. Goli, A.H., M. Barzegar and M.A. Sahari, 2005. Antioxidant activity and total phenolic compounds of pistachio (Pistachia vera) hull extracts. Food Chem., 92: 521-525.

35. Blois, M.S., 1958. Antioxidant determinations by the use of a stable free radical. Nat., 181: 1199-1200.

36. Orhan, I., S. Kusmenoglu and B. Sener, 2002. Fatty acid profile of fresh and dried banana (Musa sapientum L. var. cavendishii Lamb.) Peel Oils. J. Fac. Pharm. Ankara, 31: 13-19.

37. Norshazila, S., I.S. Zahir, K.M. Suleiman, M.R. Aisyah and K.K. Rahim, 2010. Antioxidant levels and activities of selected seeds of Malaysian tropical fruits. Malaysian J. Nutr., 16: 149-159.

38. Dahham, S.S., M.T. Agha, Y.M. Tabana and A.M.S.A. Majid, 2015. Antioxidant activities and anticancer screening of extracts from banana fruit (Musa sapientum). Acad. J. Cancer Res., 8: 28-34.

39. Hernandez-carranza, P., R. Avila-Sosa, J.A. Guerrero-Beltran, A.R. Navarro-Cruz and E. Corona-Jimenezi et al., 2015. Optimization of antioxidant compounds extraction from fruit by-products: Apple Pomace, Orange and Banana peel. J. Food Process. Preserv., 40: 103-115.
40. Sulaiman, S.F., N.A.M. Yusoff, I.M. Eldeen, E.M. Seow, A.A.B. Sajak, Supriatno and K.L. Ooi, 2011. Correlation between total phenolic and mineral contents with antioxidant activity of eight Malaysian bananas (Musa sp.). J. Food Compos. Anal., 24: 1-10.

41. Hoe, S.T., B.S. Padam, C.S. Vairappan, M.I. Abdullah and Y.C. Fook, 2015. Effect of preparation and extraction parameters of Banana (Musa balbisiana cv. Saba) inflorescence on their antibacterial activities. Sains Malaysiana, 44: 1301-1307.

42. Kim, J.M., S.M. Chang, I.H. Kim, Y.E. Kim and J.H. Hwang et al., 2007. Design of optimal solvent for extraction of bio-active ingredients from mulberry leaves. Biochem. Eng. J., 37: 271-278.

43. Koh, G.Y., G.X. Chou and Z.J. Liu, 2009. Purification of a water extract of Chinese sweet tea plant (Rubus suavissimus S. Lee) by alcohol precipitation. J. Agric. Food Chem., 57: 5000-5006.

44. Chan, E.W.C., Y.Y. Lim and M. Omar, 2007. Antioxidant and antibacterial activity of leaves of Etlingera species (Zingi beraceae) in Peninsular Malaysia. Food Chem., 104: 1586-1593.

45. Jalani, F.F.M., S. Mohamad and W.N.S. Shahidan, 2014. Antibacterial effects of banana pulp extracts based on different extraction methods against selected microorganisms. Asian J. Biomed. Pharm. Sci., 4: 14-19.

46. Mokbel, M.S. and F. Hashinaga 2005. Antibacterial and antioxidant activities of banana (Musa, AAA cv. Cavendish) fruits peel. Am. J. Biochem. Biotechnol., 1: 125-131.

47. Ehiowemwenguan, G., A.O. Emoghene and J.E. Inetianbor, 2014. Antibacterial and phytochemical analysis of banana fruit peel. IOSR. J. Pharm., 4: 18-25.

48. El Zawawy, N.A., 2015. Antioxidant, antitumor, antimicrobial studies and quantitative phytochemical estimation of ethanolic extracts of selected fruit peels. Intl. J. Curr. Microbioogyl Apl. Sci., 4: 298-309. 